Çukurova Üniversitesi Mühendislik Fakültesi Dergisi, 36(3), ss. 735-742, Eylül 2021

Cukurova University Journal of the Faculty of Engineering, 36(3), pp. 735-742, September 2021

\title{
The Investigation of Corrosion Performance and Durability of Hydroxyapatite-Coated Titanium Implants and the Effect of Antibiotic Additives
}

\author{
Demet YAZICI ${ }^{1}$, Nilgün ALPAY², Başak DOĞRU MERT ${ }^{* 3}$ \\ ${ }^{1}$ Adana City Training and Research Hospital, Ear Nose and Throat Department, Adana \\ ${ }^{2}$ Cukurova Üniversitesi, The Faculty of Dentistry, Adana \\ ${ }^{3}$ Adana Alparslan Turkes Science and Technology University, Engineering Faculty, Energy \\ Systems Engineering Department, Adana
}

Geliş tarihi: 06.04.2021

Kabul tarihi: 13.09 .2021

\begin{abstract}
In this study, amoxicillin and potassium clavulanate were loaded as antibiotic additives to hydroxyapatite coating (L-HAP) and were used to enhance biocompatibility and corrosion resistance of titanium (Ti) in- vitro conditions. Coating was achieved using the Successive Ionic Layer Adsorption and Reaction (SILAR) process. Scanning electron microscopy (SEM) images, energy dispersive X-ray (EDX) analysis, atomic force microscopy (AFM) images, X-ray diffraction (XRD) analysis, and attenuated total reflectance-Fourier transform infrared spectroscopy (ATR-FTIR) were used to determine the surface morphology. The corrosion test was performed using electrochemical impedance spectroscopy (EIS) and polarization curves in artificial saliva at $310 \mathrm{~K}$. Furthermore the quantum chemical parameters of amoxicillin and potassium clavulanate were investigated and associated with the adsorption ability of these molecules. Results revealed that the corrosion performance of Ti was improved by L-HAP, which had a lower anodic current density and better corrosion resistance. This situation dealt with the more durable, compact film that had been produced on the surface.
\end{abstract}

Keywords: Artificial saliva, Biocompatibility, SILAR, Titanium

\section{Hidroksiapatit Kaplı Titanyum İmplantların Korozyon Performansı ve Dayanıklılığının ve Antibiyotik Katkı Maddelerinin Etkisinin Araştırıması}

\section{$\ddot{\mathbf{O z}}$}

Bu çalışmada, hidroksiapatit kaplamaya (L-HAP) antibiyotik katkı maddesi olarak ilave edilen amoksisilin ve potasyum klavulanat, in-vitro koşullarda titanyumun (Ti) biyouyumluluğunu ve korozyon direncini arttırmak için kullanılmıştır. Kaplama, Ardışık İyonik Katman Adsorpsiyon ve Reaksiyon (SILAR) yöntemi ile gerçekleştirildi. Yüzey morfolojisi, taramalı elektron mikroskobu (SEM), atomik kuvvet mikroskobu (AFM), enerji dağıtıcı X-ışını (EDX) analizi, X-ışını kırınımı (XRD) analizi, azaltılmış toplam yansıma-Fourier dönüşümlü kızı̈ötesi spektroskopisi (ATR- FTIR) ile belirlendi. Korozyon testleri, elektrokimyasal impedans spektroskopisi (EIS) ve polarizasyon eğrileri yardımıyla $310 \mathrm{~K}$ 'de yapay tükürük çözeltisinde elde edildi. Ayrıca amoksisilin ve potasyum klavulanatın kuantum kimyasal parametreleri araştırıldı ve bu moleküllerin adsorpsiyon yeteneği ile ilişkilendirildi. Sonuçlar, Ti'nin korozyon performansının, daha düşük anodik akım yoğunluğuna ve daha iyi korozyon direncine sahip olan L-HAP ile iyileştirildiğini ortaya koydu. Bu durum, yüzeyde üretilen daha dayanıklı, kompakt film ile ilişkilendirildi.

Anahtar Kelimeler: Yapay tükürük, Biyouyumluluk, SILAR, Titanyum

*Sorumlu (Corresponding author) yazar: Başak DOĞRU MERT, bdogrumert@atu.edu.tr 
The Investigation of Corrosion Performance and Durability of Hydroxyapatite-coated Titanium Implants and The Effect of Antibiotic Additives

\section{INTRODUCTION}

Hydroxyapatite $\left(\mathrm{Ca}_{10}\left(\mathrm{PO}_{4}\right)_{6}(\mathrm{OH})_{2}-\mathrm{HAP}\right)$ and titanium (Ti) are well-known and commonly used biomaterials due to high biocompatibility and physical properties [1-9]. Especially in the bone reconstructive surgery and prosthetic treatments, surgeons prefer these materials because after surgical operation, $\mathrm{Ca}^{2+}$ and $\mathrm{PO}_{4}{ }^{3-}$ ions may released and absorbed to gain repair of tissues. Furthermore titanium exhibits high corrosion resistance and it has crucial effect for human health. The corrosion happens when metals and its compounds react with their environment chemically or electrochemically and get degraded and damaged by forming oxides, hydroxyoxides and other compounds. More critically, these corrosion products have the ability to permeate tissues, causing damage to human cells. The fluids in human body consist of water, soluble oxygen, proteins and various ions like chloride, hydroxide and etc. For this reason, the human body is an extremely corrosive environment for the metals used as biomaterials $[10,11]$. This corrosive environment reduces the strength of metals. One of the solutions for preventing corrosion of these metals is coating these materials with corrosionresistant coatings as hydroxyapatite [12-17]. Therefore several scientists have been studied in this field and very impressive applications were presented. Wang et al. developed an organ-like MXene- $\mathrm{Ti}_{3} \mathrm{C}_{2}$ material that was used to immobilize hemoglobin and design \& create a mediator-free biosensor with an oxidized surface. [1]. Electrochemical deposition of hydroxyapatite on a pure $\mathrm{Ti}$ substrate was used to measure corrosion resistance in a simulated body fluid (Hank's balanced salt solution). The findings revealed that it is a biomaterial that is reasonably appropriate for bone implantation [2]. The Ag deposited HAP coatings were produced and applied on anodized $\mathrm{Ti}$, due to enhance corrosion resistance of material [3]. Mirzaee et al. [3] declared that the sample with content of $\mathrm{Ag}$ (0.05 molar ratio) had high corrosion resistance and further showed good antimicrobial efficiency (almost 99\% reduction in viable cells). In the study of Coskun et al. [4] bio-metallic CoCrMo alloys were coated with hydroxyapatite at various $\mathrm{pH}$ and corrosion performance of the layers was determined. Results showed that $\mathrm{pH}$ influenced the properties of layers (chemical composition and surface morphology) and at high $\mathrm{pH}$, HAP coating exhibit more homogenous structures and high corrosion resistance [4]. Gopi et al. claimed that carbon nanotubes (CNT) enhance strength and toughness of HAP. The addition of $1 \%$ CNT to HAP enhanced the coating's corrosion resistance and biomechanical properties [18]. Usinskas et al. [19] applied calcium titanate sub-layers and produced HAP coating on Ti with the help of solgel method further they obtained pre-heating some samples. According to the results, the morphology of the HAP thin films was not effected by surface alteration of the $\mathrm{Ti}$ substrate, but, contact angle measurements revealed that raising the number of HAP layers from 20 to 30 resulted in hydrophilic activity. Consequently many researches [15-31] showed that the biocompatibility and corrosion properties of HAP coating on Ti biomaterials could enhanced but the main phenomenon was "accelerating healing process in treatment". For this purpose antibiotic additives (amoxicillin and potassium clavulanate) were used while preparing HAP coatings. Because of the ease of the technique, the SILAR procedure was used for application. Then surface morphology and corrosion properties were clarified with SEM, EDX, AFM, XRD analysis and electrochemical techniques.

\section{MATERIAL AND METHOD}

\subsection{The Production of L-HAP Films}

The titanium (Ti) sheet (it is known that $\mathrm{Ti}$ is preferred in dentistry applications) with a thickness of $0.25 \mathrm{~mm}$ (99.7\% purity), was purchased from Sigma-Aldrich. This Ti sheet was cut $1 \times 1 \mathrm{~cm}$. The amoxicillin (Figure 1a) and potassium clavulanate (Figure 1b) were purchased from Sigma-Aldrich. $\mathrm{CaCl}_{2}$ and $\mathrm{Na}_{3} \mathrm{PO}_{4} .12 \mathrm{H}_{2} \mathrm{O}$ were purchased from Merck. The Ti was cleaned using $0.1 \mathrm{M} \mathrm{HCl}$, acetone and double distilled water for $1 \mathrm{~min}$. each in ultrasonic bath. Then HAP films were deposited as mentioned below: $\mathrm{Ti}$ sheets $(1 \times 1 \mathrm{~cm})$ were immersed into $0.1 \mathrm{M} \mathrm{CaCl}_{2}$ and kept there for $30 \mathrm{~s}$. Then immediately immersed into distilled water for $30 \mathrm{~s}$ and then immersed into $1 \mathrm{mg} / \mathrm{mL}$ amoxicillin + $1 \mathrm{mg} / \mathrm{mL}$ potassium clavulanate +0.05 $\mathrm{M} \mathrm{Na} 3 \mathrm{PO}_{4} .12 \mathrm{H}_{2} \mathrm{O}$ and kept there for another $30 \mathrm{~s}$ 
after being taken out from the bath. This process is called to be one SILAR cycle. Due to get a reasonably thick film (almost $10 \mu \mathrm{m}$ ), the cycle has to be repeated 50 times at room temperature

\subsection{Characterization of L-HAP Films}

Scanning electron microscopy (SEM) and atomic force microscopy (AFM) were used to study the surface morphology of electrodes. A Carl Zeiss Evo 40 SEM was used to obtain the SEM images. The Park SYSTEMS instrument was used to obtain the AFM images. The chemical composition was determined by energy dispersive X-ray spectrometer (EDX) which is part of SEM device. ATR-FTIR spectroscopy was used to evaluate the chemical composition of L-HAP. The X-ray diffraction (XRD) pattern was recorded on a Bruker AXS D8 with $\mathrm{CuK} \alpha$ radiation $(\lambda=0.15406 \mathrm{~nm})$ in the $2 \theta$ range of $10-90^{\circ}$.

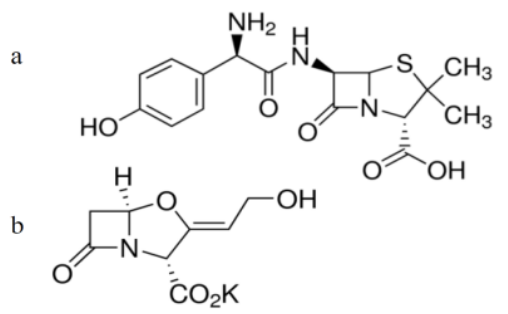

Figure 1. The molecular structure of amoxicillin (a) and potassium clavulanate (b)

\subsection{Electrochemical Measurements}

The corrosion tests were performed at $310 \mathrm{~K}$, which was body temperature, open to the atmosphere, using a CHI 604D A.C. electrochemical analyzer
(R0633). The counter electrode was a platinum sheet with a surface area of $2 \mathrm{~cm}^{2}$ and the reference electrode was an $\mathrm{Ag} / \mathrm{AgCl}(3 \mathrm{M} \mathrm{KCl})$ electrode. The corrosion performance of electrodes were investigated in artificial saliva. The composition of artificial saliva was given below [11]: $0.4 \mathrm{~g} / \mathrm{L} \mathrm{NaCl}$, $0.4 \mathrm{~g} / \mathrm{L} \mathrm{KCl}, 0.6 \mathrm{~g} / \mathrm{L} \mathrm{CaCl}_{2}, 0.54 \mathrm{~g} / \mathrm{L} \mathrm{NaH}_{2} \mathrm{PO}_{4}$ and $1 \mathrm{~g} / \mathrm{L}$ urea ( $\mathrm{pH}:$ 6.6). The EIS (electrochemical impedance spectroscopy) experiments were conducted in the frequency range with high limit of $100 \mathrm{kHz}$ and low limit of $0.01 \mathrm{~Hz}$. The amplitude was $0.005 \mathrm{~V}$. The polarization curves were potentiodynamically obtained between 1.30 and $1.75 \mathrm{~V}$ with a scan rate of $1 \mathrm{mV} \mathrm{s}^{-1}$.

\section{RESULTS AND DISCUSSION}

In Figure 2a, the SEM micrograph of L-HAP coated Ti surface is demonstrated. As seen in Fig. 2a, the electrode surface is nodular and narrow porous areas are seen between nodules. Usinskas et al. [19] present nodular views for HAP on Ti without initial pre-heating. According to Gopi et al. [25], the presence of pores on the HAP composite coating is advantageous for the initiation of bone formation by providing an excess of sites for osseous tissue growth. Rafieerad et al. [29] claimed that porous and nodular morphology enhances osteoblast adhesion, proliferation and accelerates the healing process and promotes bone mineralization. Therefore this new L-HAP coating should be suitable for surgical operations. Due to figure out contribution of antibiotics to HAP layer EDX analysis is present in Figure $2 \mathrm{~b} . \% 16.8 \mathrm{C}$ is proved that amoxicillin and potassium clavulanate loaded in HAP [25].
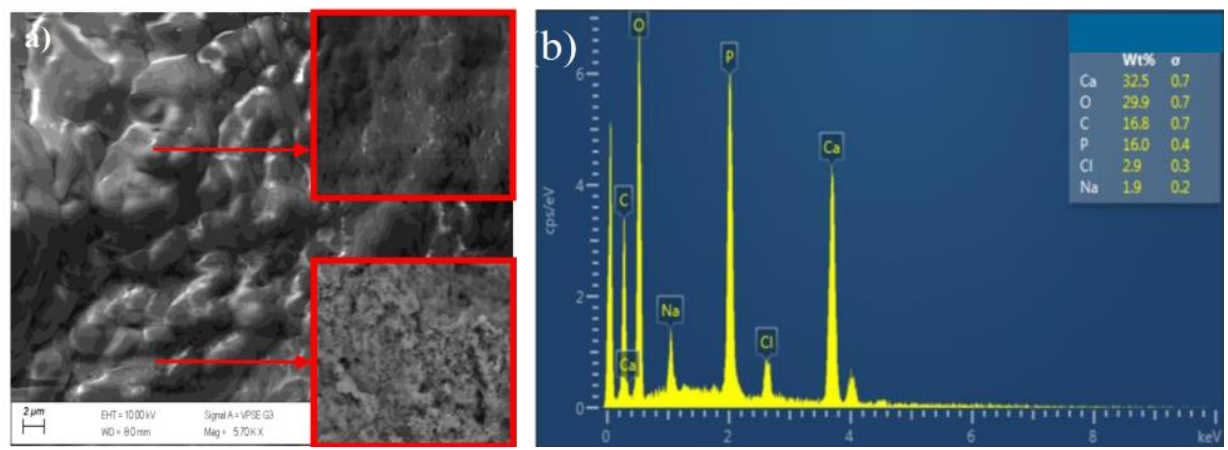

Figure 2. SEM micrographs (a) and EDX spectrum (b) of Ti/L-HAP 
The Investigation of Corrosion Performance and Durability of Hydroxyapatite-coated Titanium Implants and The Effect of Antibiotic Additives

In Figure 3, the AFM results of L-HAP coated Ti surface is presented. 2D image (Figure 3a) correlated the SEM micrograph. The nodular structures and blackberry type shapes are seen in Figure 3b. According to section analysis (Figure 3c), the average surface porosity of LHAP is almost $240 \mathrm{~nm}$. The adhesion of coating increase with increasing roughness and porosity [32] therefore L-HAP coating may increase osteoblast adhesion.

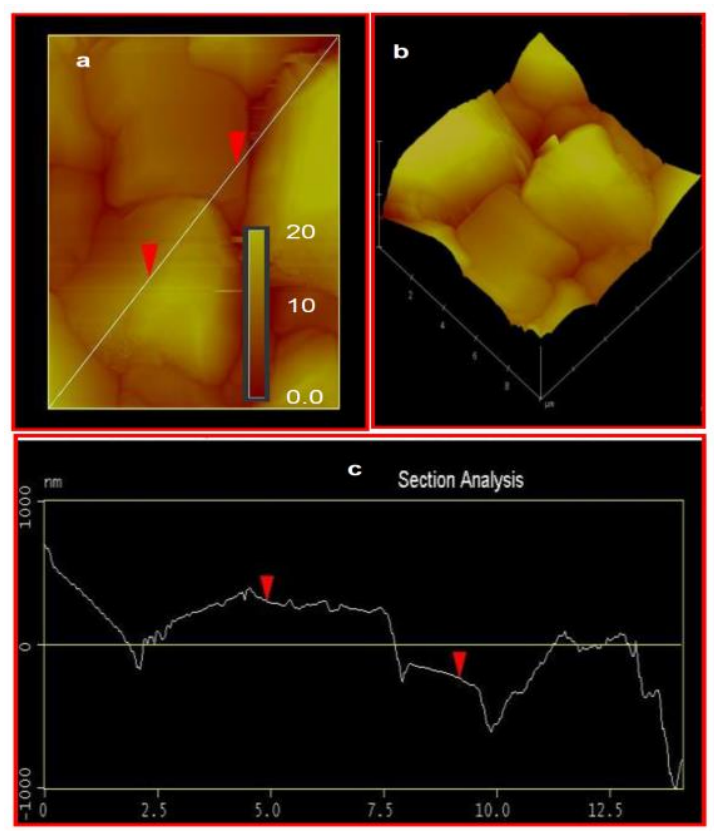

Figure 3. 2D (a), 3D (b) AFM images, and sectional analysis (c) of Ti/L-HAP (scan size: $10 \mu \mathrm{mx} 10 \mu \mathrm{m}$, scan rate: $1.001 \mathrm{~Hz})$

The ATR-FTIR spectrum of L-HAP is presented in Figure $4, \mathrm{PO}_{4}{ }^{3-}$ group of HAP is seen at $560.08 \mathrm{~cm}^{-}$ 1 , wagging mode of $\mathrm{NH}_{2}$ of amoxicillin and $\mathrm{v}_{4}$ mode of $\mathrm{PO}_{4}{ }^{3-}$ are obtained at 600 and $601.81 \mathrm{~cm}^{-1}$. Jankovic et al. [17] presented almost same results for HAP and declared that vibrational bands at 601 and $560 \mathrm{~cm}^{-1}$, corresponding to the $v_{4}$ mode of $\mathrm{PO}_{4}{ }^{3-}$ group. Indira et al. [31] enounced that $\mathrm{v}_{3}$ mode of $\mathrm{PO}_{4}{ }^{3-}$ group is seen at $1030 \mathrm{~cm}^{-1}$ and in this study it is detected at $1021.10 \mathrm{~cm}^{-1}$. Secondary amine peak of potassium clavulanate and amoxicillin is seen almost $1412.82 \mathrm{~cm}^{-1}$ and streching of $\mathrm{N}-\mathrm{H}$ and $\mathrm{O}-\mathrm{H}$ is obtained at 3378.86 $\mathrm{cm}^{-1}$. Furthermore, $v$ aromatic $(\mathrm{C}-\mathrm{H})$ is seen almost $1100.50 \mathrm{~cm}^{-1}$ and bending mode of $\mathrm{OH}$ is obtained at $1650 \mathrm{~cm}^{-1}$. The $\mathrm{O}_{3}$ and $\mathrm{v}_{4}$ mode of $\mathrm{PO}_{4}{ }^{3-}$ group and $\mathrm{O}-\mathrm{H}$ bond of carboxylic acid group is seen at $3735.07 \mathrm{~cm}^{-1}$ [33-35]. Consequently, Figure 4 proved that amoxicillin and potassium clavulanate loaded to hydroxyapatite coating.

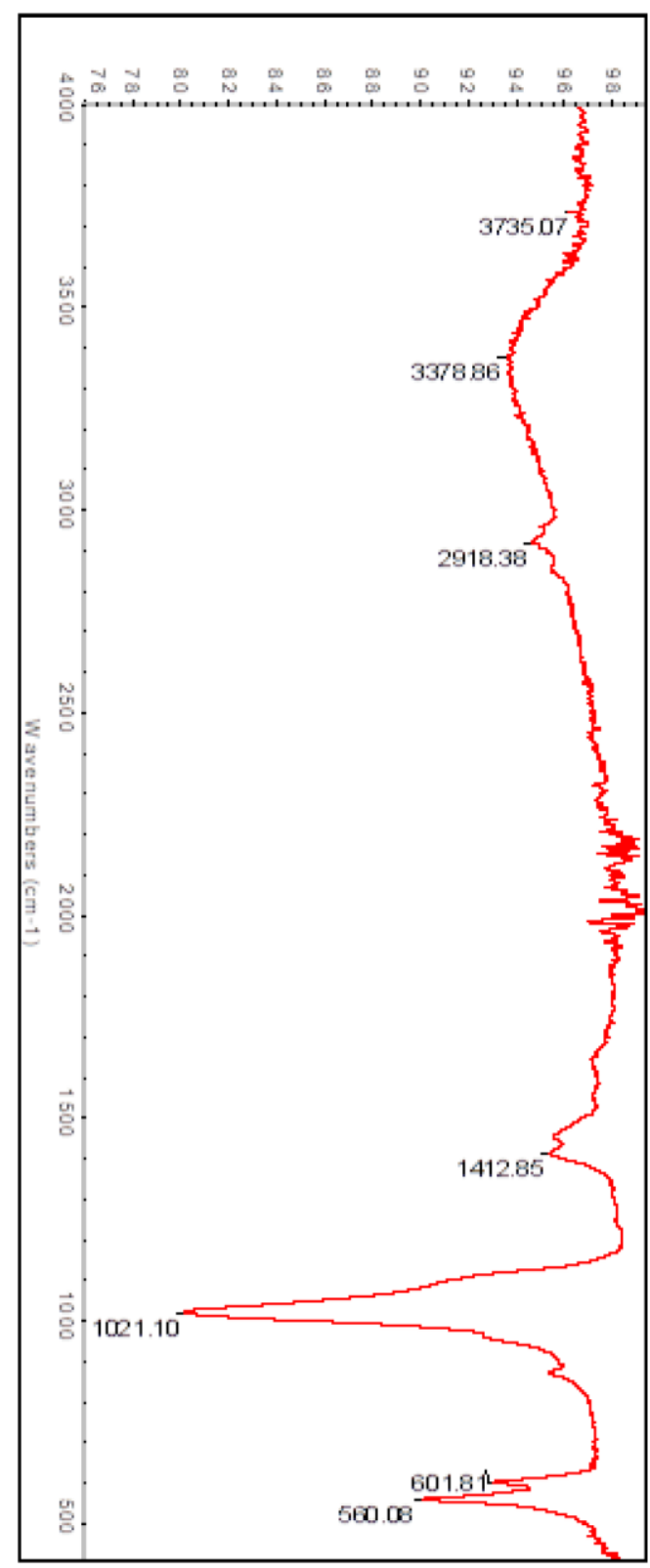

Figure 4. FTIR spectra of L-HAP 
The XRD pattern of Ti/L-HAP is given in Figure 5. The peaks at $32.18^{\circ}, 32.58^{\circ}$ and $46.78^{\circ}$ are assigned to (112), (300) and (222) planes of HAP, respectively. The peaks at $36.24^{\circ}, 39.32^{\circ}$ and $52.96^{\circ}$ are assigned to (002), (101) and (102) phases of $\mathrm{Ti}$, respectively $[17,18,33,36,37]$. High intensity of peaks reveals that L-HAP is obtained on $\mathrm{Ti}$ and results correlates the ATR-FTIR analysis.

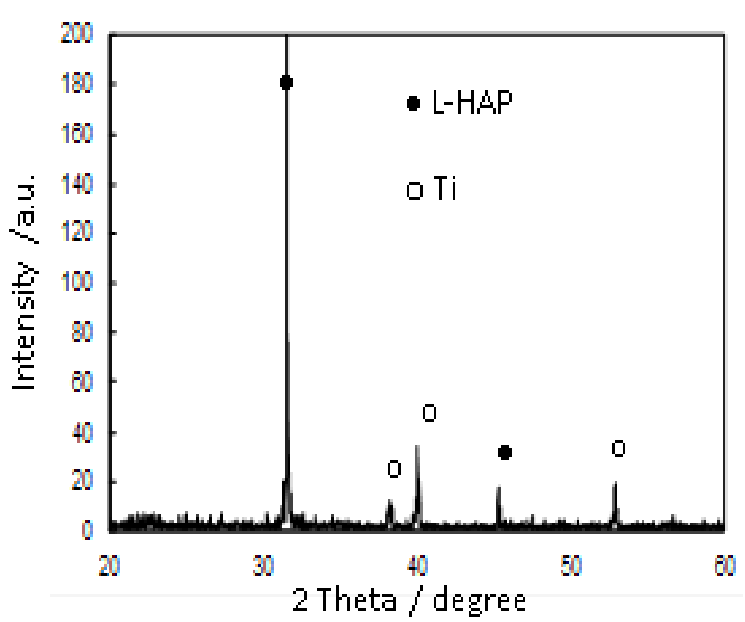

Figure 5. XRD pattern of Ti/L-HAP

The Nyquist plots of $\mathrm{Ti}$ and Ti/L-HAP, after $2 \mathrm{~h}$ immersion time in artificial saliva at $310 \mathrm{~K}$, are presented in Figure 6. The semi-circular shape with a diameter of $1.2 \times 10^{4} / \Omega \mathrm{cm}^{2}$ is seen for Ti which is attributed to charge transfer controlled corrosion reaction $[38,39]$. The maximum phase angle is $70.3^{\circ}$ (Figure 7). The EIS result of electrode has significantly changed by L-HAP coating. In Figure 5, for Ti/L-HAP, non-closed curve is seen. In the high frequency region (at 100 $\mathrm{Hz}$ ), the resistance is almost $126 \Omega \mathrm{cm}^{2}$ and this region is attributed to corrosion process occurring within pores of L-HAP layer. The resistant and phase angle at $0.01 \mathrm{~Hz}$ are almost $1.8 \times 10^{4} / \Omega \mathrm{cm}^{2}$ and $75.4^{\circ}$ (Figure 7 ), respectively and this region is attributed to the L-HAP film resistance. According to EIS results of these electrodes, LHAP has protective effect against corrosion in artificial saliva at $310 \mathrm{~K}$. Due to further insight, the polarization curves are presented in Figure 8.

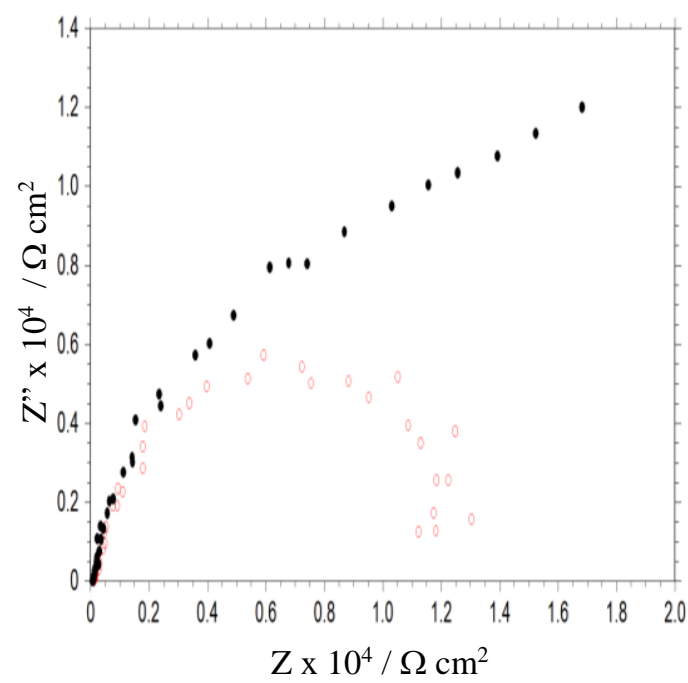

Figure 6. The Nyquist plots of $\mathrm{Ti}$ (o) and $\mathrm{Ti} / \mathrm{L}-$ HAP (•) after $2 \mathrm{~h}$ immersion time in artificial saliva at $310 \mathrm{~K}$

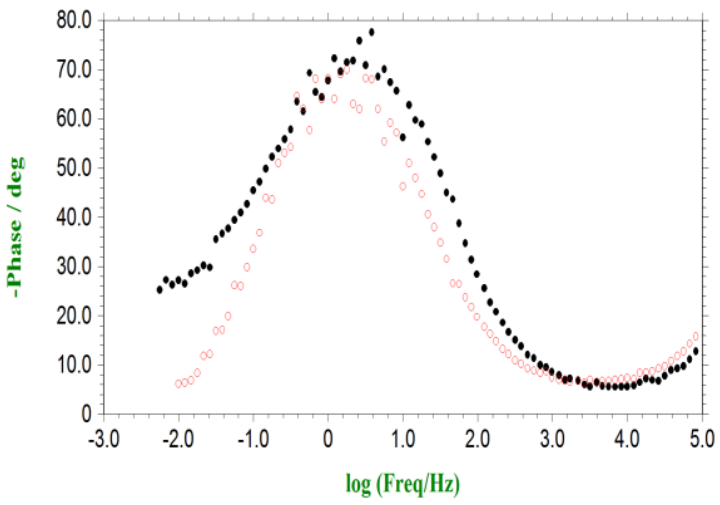

Figure 7. The log freq-phase deg. plots of $\mathrm{Ti}(\mathrm{O})$ and Ti/L-HAP $(\bullet)$ after $2 \mathrm{~h}$ immersion time in artificial saliva at $310 \mathrm{~K}$

In Figure 8, the corrosion potentials (Ecorr) of $\mathrm{Ti}$ and Ti/L-HAP are 1.43 and $1.64 \mathrm{~V}$ (vs. $\mathrm{Ag} / \mathrm{AgCl}$ ), respectively. The nobler (more positive) Ecorr reflects high corrosion protection [40]. Furthermore lower cathodic and anodic current density are seen for Ti/L-HAP and it correlates with EIS measurements. As Radha said that [41], the electroless hydroxyapatite coating technique is most effective and economical way of coating metal . Consequently, results show that L-HAP protect $\mathrm{Ti}$ against corrosion effectively. 
The Investigation of Corrosion Performance and Durability of Hydroxyapatite-coated Titanium Implants and The Effect of Antibiotic Additives

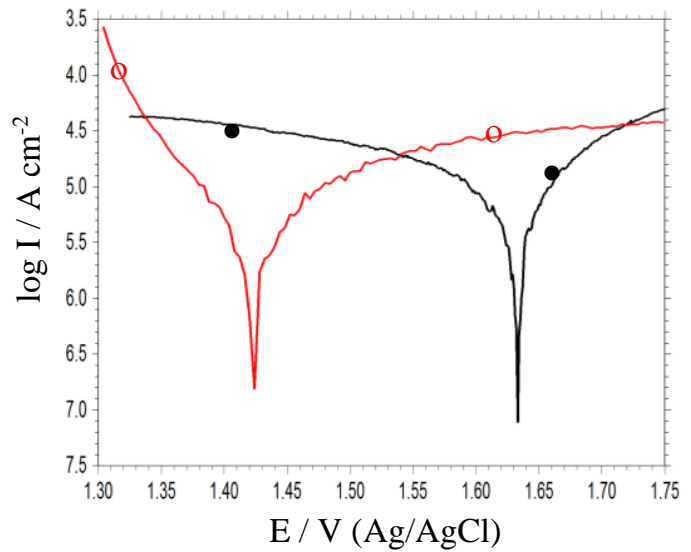

Figure 8. The polarization curves of $\mathrm{Ti}(\mathrm{O})$ and Ti/L-HAP $(\bullet)$ after $2 \mathrm{~h}$ immersion time in artificial saliva at $310 \mathrm{~K}$

\section{CONCLUSION}

The antibiotic loaded hydroxyapatite coating (LHAP) was produced by Successive Ionic Layer Adsorption and Reaction (SILAR) method and corrosion performance was investigated in-vitro conditions. The ATR-FTIR, EDX and XRD results showed that, HAP coating was produced as a $\mathrm{Ca}_{10}\left(\mathrm{PO}_{4}\right)_{6}(\mathrm{OH})_{2}$ chemical form and amoxicillin and potassium clavulanate penetrate the interior of HAP. The scanning electron microscopy (SEM) and atomic force microscopy (AFM) results exhibited rough surface, which was beneficial for osteoblast adhesion, proliferation. The electrochemical measurements supported that LHAP is a convenient coating against corrosion in artificial saliva at body temperature. Especially the $\mathrm{E}_{\text {corr }}$ of Ti/L-HAP was denoted a high level of corrosion resistance with the value of $1.64 \mathrm{~V}$ but the $\mathrm{E}_{\text {corr }}$ of bare sample was $1.43 \mathrm{~V}$. For Ti/L-HAP, the resistance which was determined with the help of electrochemical impedance spectroscopy, at $0.01 \mathrm{~Hz}$ was $1.8 \times 10^{4} / \Omega \mathrm{cm}^{2}$, indicated high corrosion resistance.

\section{KAYNAKLAR}

1. Wang F., Yang C., Duan C., Xiao D., Tang Y., Zhu J., 2015. An Organ-like Titanium Carbide Material (MXene) with Multilayer Structure
Encapsulating Hemoglobin for a Mediator-free Biosensor. Journal of the Electrochemical Society, 162(1), 16-21.

2. Chen, S., Tsai, W., Chen, P., Fang, A., Say, W., 2016. Influence of Applied Voltages on Mechanical Properties and In-vitro Performances of Electroplated Hydroxyapatite Coatings on Pure Titanium. Journal of The Electrochemical Society, 163(7), 305-308.

3. Mirzaee, M., Vaezi, M., Palizdar, Y., 2016. Synthesis and Characterization of Silver Doped Hydroxyapatite Nanocomposite Coatings and Evaluation of Their Antibacterial and Corrosion Resistance Properties in Simulated Body Fluid. Materials Science and Engineering, 69, 675-684.

4. Coşkun, M., Karahan, I., Golden, T., 2015. Computer Assisted Corrosion Analysis of Hydroxyapatite Coated CoCrMo Biomedical Alloys. Surface\&Coatings Technology, 275, 1-9.

5. Wang, H., Lin, C., Hu, R., Xu, Y., 2007. Electrochemical Deposition of Nano-micro Structured Octacalcium Phosphate/protein Composite Coating on Titanium for Biomedical Applications. ECS Transactions, 3(19), 21-26.

6. Shiha, Y., Tsai, M., Ou, K., 2007. Effect of Oxide Film Containing Fluorine Ion on Enhancing the Initial Osseointegration of Titanium-based Alloy. ECS Transactions, 6(15), 21-33.

7. Matykina, E., Monfort, F., Berkani, A., Skeldon, P., Thompson, G., Gough, J., 2007. Characterization of Spark-anodized Titanium for Biomedical Applications. Journal of the Electrochemical Society, 154(6), 279-285.

8. Ouerd, A., Alemany-Dumont, C., Berthomé, G., Normand, B., Szunerits, S., 2007. I. Electrochemical Characterization of the Metal/Protein Interface. Journal of The Electrochemical Society, 154(6), 593-601.

9. Kim, J., Leez, K., 2009. Dependence of the Morphology of Nanostructured Titanium Oxide on Fluoride Ion Content. Electrochemical and Solid-State Letters, 12(3), 10-12.

10. Dunne, C., Levy, G., Hakimi, O., Aghionb, E., Twomey, B., Stanton, K., 2016. Corrosion Behaviour of Biodegradable Magnesium 
Alloys with Hydroxyapatite Coatings. Surface \& Coatings Technology, 289, 37-44.

11. Pina, V., Amigo, V., Munoz, I., 2016. Microstructural, Electrochemical and Triboelectrochemical Characterisation of Titaniumcopper Biomedical Alloys. Corrosion Science, 109, 115-125.

12. Take, S., Kikuchi, K., Suda, S., Izawa, S., Itoi, Y., 2014. Preparation and Evaluation of $\mathrm{Zn}$ Doped HAp Plasma Spray Biocombatible Coatings on Titanium. ECS Transactions, 58, 17-22.

13. Dehestani, M., Adolfsson, E., Stanciu, L., 2016. Mechanical Properties and Corrosion Behavior of Powder Metallurgy Ironhydroxyapatite Composites for Biodegradable İmplant Applications. Materials and Design, 109, 556-569.

14. Anjaneyulu, U., Vijayalakshmi, U., 2017. Preparation and Characterization of Novel Solgel Derived Hydroxyapatite $/ \mathrm{Fe}_{3} \mathrm{O}_{4}$ Composites Coatings on Ti-6Al-4V for Biomedical Applications. Materials Letters, 189, 118-121.

15. Akazem, F., Kiss, A., Birlik, I, Braic, V., Luculescu, C., Vladescu, A., 2014. The Corrosion and Bioactivity Behavior of $\mathrm{SiC}$ Doped Hydroxyapatite for Dental Applications. Ceramics International, 40, 15881-15887.

16. Otsuka, Y., Kojima, D., Mutoh, Y., 2016. Prediction of Cyclic Delamination Lives of Plasma-sprayed Hydroxyapatite Coating on Ti6Al-4V Substrates with Considering Wear and Dissolutions. Journal of the Mechanical Behavior of Biomedical Materials, 64, 113124.

17. Jankovic, A., Eraković, S., Mitrić, M., Matić, I.Z., Juranić, Z.D., Tsui, G.C.P., Tang, C.Y., Mišković-Stanković, M., Rhee, K.Y., Park, S.J., 2015. Bioactive Hydroxyapatite/graphene Composite Coating and its Corrosion Stability in Simulated Body Fluid. Journal of Alloys and Compounds, 624,148-157.

18. Gopi, D., Shinyjoy, E., Sekar, M., Surendiran, M., Kavitha, L., Sampath Kumar, T., 2013. Development of Carbon Nanotubes Reinforced Hydroxyapatite Composite Coatings on Titanium by Electrodeposition Method. Corrosion Science, 73, 321-330.
19. Usinskas, P., Stankeviciute, Z., Beganskiene, A., Kareiva, A., 2016. Sol-gel Derived Porous and Hydrophilic Calcium Hydroxyapatite Coating on Modified Titanium Substrate. Surface Coatings Technology, 307, 935-940.

20. Palanivelu, R., Kumar, A., 2014. Scratch and Wear Behaviour of Plasma Sprayed Nano Ceramics Bilayer $\quad \mathrm{Al}_{2} \mathrm{O}_{3}-13 \quad$ wt $\%$ $\mathrm{TiO}_{2} /$ hydroxyapatite Coated on Medical Grade Titanium Substrates in SBF Environment. Applied Surface Science, 315, 372-379.

21. Huang, Y., Ding, Q., Panga, X., Han, S., Yan, Y., 2013. Corrosion Behavior and Biocompatibility of Strontium and Flüorine Co-doped Electrodeposited Hydroxyapatite Coatings. Applied Surface Science, 282, 456-462.

22. Asri, R.I.M., Harun, W.S.W., Hassan, M.A., Ghani, S.A.C., Buyongc, Z., 2016. A Review of Hydroxyapatite-based Coating Techniques: Sol-gel and Electrochemical Depositions on Biocompatible Metals. Journal of the Mechanical Behavior of Biomedical Materials, 57, 95-108.

23. Metikos-Hukovic, M., Tkalcec, E., Kwokala, I., Piljac, J., 2003. An in Vitro Study of Ti and Ti-Alloys Coated with Sol-gel Derived Hydroxyapatite Coatings. Surface Coatings Technology, 165, 40-50.

24. Suchanek, K., Hajdya, M., Maximenko, A., Zarzycki, A., Marszaek, M., Jany, B.R., Krok, F., 2017. The Influence of Nanoporous Anodic Titanium Oxide Substrates on the Growth of the Crystalline Hydroxyapatite Coatings. Materials Chemistry Physics, 186, 167-178.

25. Gopi, D., Shinyjoya, E., Kavithac, L., 2015. Influence of Ioni Csubstitution in Improving the Biological Property of Carbon Nanotubes Reinforced Hydroxyapatite Composite Coating on Titanium for Orthopedic Applications. Ceram. Int. 41, 5454-5463.

26. Yan, Y., Zhang, X., Mao, H., Huang, Y., Ding, Q., Pang, X., 2015. Hydroxyapatite/gelatin Functionalized Graphene Oxide Composite Coatings Deposited on $\mathrm{TiO}_{2}$ Nanotube by Electrochemical Deposition for Biomedical Applications. Applied Surface Science, 329, 76-82. 
The Investigation of Corrosion Performance and Durability of Hydroxyapatite-coated Titanium Implants and The Effect of Antibiotic Additives

27. Mohan, L., Durgalakshmi, D., Geeth, M., Sankara Narayanan, T.S.N., Asokamani, R., 2012. Electrophoretic Deposition of Nanocomposite $\left(\mathrm{HAp}+\mathrm{TiO}_{2}\right)$ on Titanium Alloy for Biomedical Applications. Ceram. Int., 41(38), 3435-3443.

28. Gopi, D., Karthika, A., Rajeswari, D., Kavitha, L., Pramodd, R., Dwivedid, J., 2014. Evaluation of the Mechanical and Corrosion Protection Performance of Electrodeposited Hydroxyapatite on the High Energy Electron Beam Treated Titanium Alloy. Journal of Alloys and Compounds, 616, 498-504.

29. Rafieerad, A., Ashra, M.R., Mahmoodian, R., Bushroa, A.R., 2015. Surface Characterization and Corrosion Behavior of Calcium Phosphatebase Composite Layer on Titanium and its Alloys Via Plasma Electrolytic Oxidation: A Review Paper. Material Science Enineering, 57, 397-413.

30. Ripamonti, U., Roden, L.C., Renton, L.F., 2012. Osteoinductive Hydroxyapatite-coated Titanium Implants. Biomaterials, 33, 3818-3823.

31. Indira, K., Mudali, U.K., Rajendran, N., 2014. In Vitro Bioactivity and Corrosion Resistance of $\mathrm{Zr}$ Incorporated $\mathrm{TiO}_{2}$ Nanotube Arrays for Orthopaedic Applications. Applied Surface Science, 316, 264-275.

32. Roh, H.S., Jung, S.C., Kook, M.S., Kim, B.H., 2016. In Vitro Study of 3D PLGA/n-HAp/ßTCP Composite Scaffolds Withetched Oxygen Plasma Surface Modification in Bone Tissue Engineering. Applied Surface Science, 388, 321-330.

33. Kalsoom, U., Bashir, S., Ali, N., 2013. SEM, AFM, EDX and XRD Analysis of Laser Ablated $\mathrm{Ti}$ in Nonreactive and Reactive Ambient Environments. Surface Coatings Technology, 235, 297-302.

34. Romaraj, R., Taryba, M.G., Morozov, Y., 2021. On the Synergistic Corrosion Inhibition and Polymer Healing Effects of Polyolefin Coatings Modified with Ce-loaded Hydroxyapatite Particles Applied on Steel. Electrochimica Acta, 388, 138648-138660.

35. Srikant, T., Mishra, S.B., 2021. Post Annealing Effect on Corrosion Behavior, Bacterial Adhesion, and Bioactivity of LVOF Sprayed
Hydroxyapatite Coating. Surface\&Coatings Technology, 405, 126500-126515.

36. Jing, Z., Qianqian, C., Hu, J., 2021. Corrosion, Wear and Biocompatibility of Hydroxyapatite Bio-functionally Graded Coating on Titanium Alloy Surface Prepared by Laser Cladding. Ceramics International, 47, 24641-24651.

37. Siveraj, D., Kalimuthu, V., Arumugam, G., 2020. Tailoring $\mathrm{Cu}$ Substituted Hydroxyapatite/functionalized Multiwalled Carbon Nanotube Composite Coating on 316L SS Implant for Enhanced Corrosion Resistance, Antibacterial and Bioactive Properties. International Journal of Pharmaceutics, 590, 119946-119958.

38. Wen, S., Xianglei, L., Jiahui, D., Yulai, L., Ziting, L., Zimeng, Z., Guangmeng, C., 2021. Hydrothermal Synthesis of Hydroxyapatite Coating on the Surface of Medical Magnesium Alloy and its Corrosion Resistance. Progress in Natural Science: Materials International, 31, 324-333.

39. Shanaghia, A., Mehrjoub, Z., Ahmadiana, A.R., Souria, P., Chub, K., 2021. Enhanced Corrosion Resistance, Antibacterial Properties, and Biocompatibility by Hierarchical Hydroxyapatite/ciprofloxacin-calcium Phosphate Coating on Nitrided NiTi Alloy. Materials Science\&Engineering, 118, 111524- 111540.

40. Senthilkumar, G., Saravanan, K.G., Vignesh, P., Sudharshan Vishwak, R., Nivin Joy, T., Hemanandh, J., 2021. Hydroxyapatitebarium/strontium Titanate Composite Coatings for Better Mechanical, Corrosion and Biological Performance. Materials Today: Proceedings, 44, 3618-3621.

41. Radha, R., Sreekanth, D., 2020. Electroless Tin Coated Hydroxyapatite Reinforced MgSn Alloy Composite for Enhanced Bio Corrosion Resistance and Bioactivity. Comp. Communications, 21, 100372-100379. 